TABLE III-Average durations of stay of patients admitted with appendicitis to 22 major hospitals in Wales during 1976 and numbers of such patients*

\begin{tabular}{|c|c|c|}
\hline $\begin{array}{l}\text { Health } \\
\text { district }\end{array}$ & $\begin{array}{l}\text { Average siay in } \\
\text { days in each hospital }\end{array}$ & $\begin{array}{l}\text { No } \sim f \text { patients } \\
\text { admitted }\end{array}$ \\
\hline A & $\begin{array}{l}7 \cdot 3 \\
\end{array}$ & 283 \\
\hline & $\begin{array}{l}6 \cdot 7 \\
6 \cdot 0\end{array}$ & $\begin{array}{l}362 \\
177\end{array}$ \\
\hline & $6 \cdot 0$ & 139 \\
\hline D & $\begin{array}{l}7 \cdot 6 \\
7 \cdot 5\end{array}$ & $\begin{array}{l}222 \\
177\end{array}$ \\
\hline $\mathbf{E}$ & $6 \cdot 7$ & 392 \\
\hline $\begin{array}{l}\mathbf{F} \\
\mathbf{G}\end{array}$ & $\begin{array}{l}8 \cdot 7 \\
6 \cdot 6\end{array}$ & $\begin{array}{l}213 \\
291\end{array}$ \\
\hline $\mathbf{H}$ & $9 \cdot 9$ & 102 \\
\hline & $7 \cdot 4$ & 99 \\
\hline J & $9^{\dagger} \cdot \mathbf{4}$ & ${ }_{324}^{\dagger}$ \\
\hline $\mathbf{K}$ & 6.0 & 265 \\
\hline L & $\begin{array}{l}7 \cdot 8 \\
9 \cdot 2\end{array}$ & $\begin{array}{l}262 \\
160\end{array}$ \\
\hline $\mathbf{M}$ & 8.9 & $\begin{array}{l}100 \\
174\end{array}$ \\
\hline $\mathbf{N}$ & $\begin{array}{l}8 \cdot 1 \\
6.9\end{array}$ & $\begin{array}{l}306 \\
199\end{array}$ \\
\hline $\mathbf{O}$ & + & + \\
\hline $\mathbf{P}$ & $\begin{array}{l}7 \cdot 4 \\
8 \cdot 1\end{array}$ & $\begin{array}{l}329 \\
207\end{array}$ \\
\hline $\mathbf{Q}$ & $\begin{array}{l}8.5 \\
9.3\end{array}$ & $\begin{array}{r}91 \\
211\end{array}$ \\
\hline Tot & $7 \cdot 6$ & \\
\hline
\end{tabular}

*Ninety-six percent of patients admitted to hospitals in Wales were admitted to thes

22 major hospitals.

health district in south Wales with another in north Wales. Furthermore, the large variation in admission rates analysed by day of the week implies that, although appendicitis is generally considered to be an emergency necessitating immediate admission, there is some freedom of choice regarding the day of admission. The differences between admission rates on weekdays and at weekends are more likely to be causally associated with the availability of general practitioners and ease of access to hospital than with daily differences in the onset of pain. In addition, the negative association between age-standardised admission rates and the average durations of stay may be viewed as an indication of the limited physical resources in hospitals-namely, beds, theatres, and surgical and nursing staff-per caput of population. In districts in which many patients consult for appendictis or where general practitioners refer many patients with appendicitis the hospitals are likely to discharge inpatients earlier in order to clear beds for further referrals. On the other hand, in districts served by hospitals in which the duration of stay is longer the non-availability of beds may produce a "waiting-list effect" and hence may reduce the rate of referral to hospital.

We therefore suggest that much of the variation between districts in hospital admission rates may be explained not by a difference in incidence caused by genetic ${ }^{5}$ or dietary ${ }^{2}$ factors but by differences in hospital admission policies. The other variation observed - that in hospital admissions analysed by day of weekand the negative association between admission rates and duration of stay also provide supportive evidence that the admission to hospital of patients with appendicitis is not entirely governed by the sudden onset of abdominal pain: other contributing factors include the threshold of consultation of each patient, the referral habits of his general practitioner, the availability of hospital beds, and the general expectation of the community based on these factors and on the past admission rates of local hospitals.

This paper is based on a community medicine project by MJC.

\section{References}

1 West, R R, and Roberts, C J, International fournal of Epidemiology, 1974, 3, 351 .

2 Burkitt, D P, British fournal of Surgery, 1971, 58, 695.

${ }^{3}$ Lichtner, G, and Pflanz, M, Medical Care, 1971, 9, 311.

4 Department of Health and Social Security, Report on Hospital Inpatient Enquiry 1972. London, HMSO, 1974.

5 Ashley, D J B, and Davies, H D, Gut, 1966, 7, 542.

\title{
Factors influencing postoperative morbidity and mortality in patients treated with bleomycin*
}

\author{
PAUL L GOLDINER, GRAZIANO C CARLON, ESTEBAN CVITKOVIC, \\ OLGA SCHWEIZER, WILLIAM S HOWLAND
}

British Medical fournal, 1978, 1, 1664-1667

\section{Summary and conclusions}

Patients treated with bleomycin are at risk of developing the acute adult respiratory distress syndrome postoperatively. In a prospective study of 12 patients who had received bleomycin preoperatively and were under-

*Presented in part at the World Congress of Critical Care Medicine, Paris, 19-23 September 1977

Memorial Sloan-Kettering Cancer Centre, New York, NY 10021

PAUL L GOLDINER, MD, associate chairman, department of anaesthesiology

GRAZIANO C CARLON, MD, co-director, critical-care unit

ESTEBAN CVITKOVIC, MD, associate physician, solid tumour service, department of medicine

OLGA SCHWEIZER, MD, attending anaesthesiologist

WILLIAM S HOWLAND, MD, chairman, department of anaesthesiology going removal of retroperitoneal lymph nodes or pulmonary metastases several preventive factors were established. These were the use of low concentrations of inspired oxygen during operation and in the immediate postoperative period, careful monitoring of fluid replacement, and restriction of crystalloids in favour of colloids.

\section{Introduction}

Bleomycin, an antibiotic synthetised from Streptomyces verticillus, is highly effective against many malignant diseases, including dysgenetic neoplasm of the testes. ${ }^{1-3}$ Among its side effects, however, the most important is interstitial pneumonia occurring during administration of the drug, followed by chronic fibrotic changes in the lung. ${ }^{4-10}$

Bleomycin is extensively used at this centre for metastatic embryonal-cell carcinoma or teratoma of the testicle. Until 1974 the protocol was orchiectomy followed by chemotherapy with vinblastine and cyclophosphamide, retroperitoneal node dis- 
section, and eventually treatment of the metastases with bleomycin. Current practice is to remove the diseased testicle, administer $200-400 \mathrm{mg}$ bleomycin $/ \mathrm{m}^{2}$, and six to 12 months later remove the retroperitoneal lymph nodes or pulmonary metastases surgically. With this protocol the lymph nodes show no metastatic disease on removal but are fibrotic and sclerotic. They are large, however, and the operation is usually long and difficult, often including resection of the large bowel, inferior vena cava, and abdominal aorta and removal of one kidney. Blood loss is often 10-15 units or more, and the overall duration of the operation is about six to eight hours.

The first five patients who received bleomycin according to the new protocol developed severe respiratory distress three to five days after removal of the retroperitoneal lymph nodes or pulmonary metastases. Despite mechanical ventilatory support, positive end-expiratory pressure, and, in one case, eight days of extracorporeal membrane oxygenation all five patients died from inexorably progressing interstitial pneumonia. Necropsy in each case disclosed increased lung size and weight and abnormal amounts of interstitial fluid. Microscopical and ultramicroscopical examination of the lung showed interstitial fibrosis, destruction of types I and II pneumonocytes, and alveolar wall and capillary damage, all consistent with the general diagnosis of adult respiratory distress syndrome. Cultures for bacterial and viral pathogens were sterile in vivo and at necropsy.

We thought that two factors might have been related to the high postoperative mortality rate in bleomycin-treated patients. One was a disproportion of crystalloid to colloid replacement, with resultant pulmonary interstitial oedema. The other was the concentration of inspired oxygen, as pulmonary lesions similar to those found at necropsy have been reported in patients with "oxygen toxicity." To test the validity of these assumptions fluid replacement was carefully monitored and relatively low fractional concentrations of inspired oxygen $\left(\mathrm{F}_{1} \mathrm{O}_{2}\right)$ were used in the operative and postoperative periods in a series of patients who had previously received bleomycin treatment. The results are presented here.

\section{Methods}

We chose 12 patients for the prospective study who matched closely the five patients who had died. Matching was for age, bleomycin dosage, incidence of pulmonary problems while taking bleomycin, residual pulmonary function at surgery, preoperative blood gas tensions and duration and extent of surgical procedures (see tables I and II). None of the 17 patients had at any time received chemotherapeutic agents besides bleomycin, or pulmonary irradiation. ${ }^{89}$ No patient had a history of pulmonary disease before the administration of bleomycin. In all patients, both survivors and nonsurvivors, anaesthesia was induced with thiopentone and maintained with nitrous oxide and oxygen, a narcotic, and a muscle relaxant. Ventilation was controlled with a volume-cycled ventilator (model 300/DO; Ohio Surgical Equipment, Wisconsin, USA), with tidal volume and rate adjusted to maintain the $\mathrm{PaCO}_{2}$ at $4 \cdot 7-5 \cdot 3 \mathrm{kPa}$ $(35-40 \mathrm{~mm} \mathrm{Hg})$.

In the 12 patients studied prospectively the $\mathrm{F}_{\mathrm{I}} \mathrm{O}_{2}$ concentration was maintained at $0 \cdot 22-0 \cdot 25$ throughout surgery, often being controlled with an oxygen analyser (model 200 oxygen monitor; Ohio Medical Products, Wisconsin). Blood gas tensions were determined several times during the operation. A Swan-Ganz catheter was inserted immediately before operation, permitting measurement of pulmonary artery and capillary wedge pressures and cardiac output. Crystalloids were administered at $3-4 \mathrm{ml} / \mathrm{kg} / \mathrm{h}$. The volume of colloids $(5 \%$ purified protein fraction or fresh frozen plasma) and whole-blood replacement was based on the cardiac output, pulmonary capillary wedge pressure, and hourly urinary output. Volumetric and gravimetric methods were used to measure blood loss. After operation the patients were returned to the special care unit, where they were maintained on room air or a $\mathrm{F}_{1} \mathrm{O}_{2}$ concentration of 0.24 regulated by Ventimask. The variables measured in the groups of survivors and non-survivors were compared by Student's $t$ test for paired data.

\section{Results}

The 12 patients studied had an uneventful postoperative course. They were discharged from the special care unit within 48 hours and left the hospital 12-25 days after operation. In contrast, the initial five patients had entered the special care unit three to five days after operation owing to pulmonary complications and died despite treatment.

Although survivors and non-survivors were closely matched for preoperative variables (table I), three differences existed postoperatively (table II). The first was the inspired oxygen concentration administered during the operation and in the immediate postoperative period. The mean $\mathrm{F}_{1} \mathrm{O}_{2}$ concentration was 0.24 in the survivors compared with 0.39 in the non-survivors $(P<0.001)$. Secondly, the survivors received a mean of $3.87 \mathrm{ml}$ crystalloids $/ \mathrm{kg} / \mathrm{h}$ intraoperatively and the non-survivors $5.86 \mathrm{ml} / \mathrm{kg} / \mathrm{h}(\mathrm{P}<0 \cdot 05)$. The survivors received more colloids than the non-survivors, although the difference was not significant. Hourly fluid balance (crystalloid intake minus urinary output) was $303 \mathrm{ml} / \mathrm{h}$ in the non-survivors and $126 \mathrm{ml} / \mathrm{h}$ in the survivors $(P<0.05)$. Thirdly, the mean preoperative alveolar-arterial oxygen pressure difference $\left(\mathrm{PA}-\mathrm{aO}_{2}\right)$ was higher than the normal

TABLE I-Preoperative details of survivors and non-survivors

\begin{tabular}{|c|c|c|c|c|c|c|}
\hline Case No & $\begin{array}{c}\text { Age } \\
\text { in years }\end{array}$ & $\begin{array}{c}\text { Bleomycin } \\
\text { dosage }(\mathrm{mg})\end{array}$ & $\begin{array}{c}\text { Interval between } \\
\text { bleomycin treatment } \\
\text { and surgery (months) }\end{array}$ & $\begin{array}{c}\text { Interstitial } \\
\text { pneumonia during } \\
\text { bleomycin treatment }\end{array}$ & $\begin{array}{l}\text { Preoperative } \\
\text { vital capacity } \\
\left({ }^{\circ} \% \text { predicted }\right)\end{array}$ & $\begin{array}{c}\text { Preoperative carbon } \\
\text { monoxide diffusion } \\
(\% \text { predicted })\end{array}$ \\
\hline \multicolumn{7}{|c|}{ Survivors } \\
\hline $\begin{array}{r}1 \\
2 \\
3 \\
4 \\
5 \\
6 \\
7 \\
8 \\
9 \\
10 \\
11 \\
12\end{array}$ & $\begin{array}{l}15 \\
29 \\
19 \\
27 \\
21 \\
30 \\
32 \\
18 \\
32 \\
34 \\
15 \\
54\end{array}$ & $\begin{array}{r}480 \\
340 \\
699 \\
1108 \\
765 \\
532 \\
779 \\
579 \\
301 \\
575 \\
616 \\
421\end{array}$ & $\begin{array}{r}8 \\
10 \\
6 \\
7 \\
11 \\
11 \\
9 \\
8 \\
12 \\
10 \\
8 \\
10\end{array}$ & $\begin{array}{l}\text { Yes } \\
\text { No } \\
\text { No } \\
\text { No } \\
\text { Yes } \\
\text { No } \\
\text { No } \\
\text { No } \\
\text { No } \\
\text { Yes } \\
\text { No } \\
\text { No }\end{array}$ & $\begin{array}{l}74 \\
92 \\
72 \\
96 \\
88 \\
61 \\
94 \\
80 \\
96 \\
80 \\
98 \\
65\end{array}$ & $\begin{array}{l}60 \\
58 \\
48 \\
55 \\
98 \\
62 \\
67 \\
81 \\
60 \\
68 \\
75 \\
58\end{array}$ \\
\hline Mean $+\mathrm{SE}$ of mean & $27 \cdot 6+3.65$ & $599+64$ & $9 \cdot 2+0.5$ & & $83+37$ & $61 \cdot 7 \pm 2 \cdot 8$ \\
\hline \multicolumn{7}{|c|}{ Non-survivors } \\
\hline $\begin{array}{l}13 \\
14 \\
15 \\
16 \\
17\end{array}$ & $\begin{array}{l}31 \\
25 \\
27 \\
21 \\
54\end{array}$ & $\begin{array}{l}420 \\
560 \\
135 \\
595 \\
420\end{array}$ & $\begin{array}{r}7 \\
12 \\
10 \\
9 \\
10\end{array}$ & $\begin{array}{l}\text { No } \\
\text { No } \\
\text { Yes } \\
\text { No } \\
\text { No }\end{array}$ & $\begin{array}{l}60 \\
94 \\
91 \\
67 \\
90\end{array}$ & $\begin{array}{l}55 \\
61 \\
50 \\
68 \\
60\end{array}$ \\
\hline Mean $\pm \mathrm{SE}$ of mean & $31 \cdot 6 \pm 5 \cdot 83$ & $426: 181$ & $9 \cdot 6+0.8$ & & $80 \cdot 5+7 \cdot 0$ & $588 \pm 3$ \\
\hline$P$ & NS & NS & NS & & NS & NS \\
\hline
\end{tabular}


TABLE II-Operative and postoperative data on survivors and non-survivors

\begin{tabular}{|c|c|c|c|c|c|c|c|c|}
\hline \multirow[t]{2}{*}{ Case No } & \multirow[t]{2}{*}{ Operation } & \multirow{2}{*}{$\begin{array}{c}\text { Duration of } \\
\text { operation (h) }\end{array}$} & \multicolumn{2}{|c|}{$\begin{array}{l}\text { intraoperative fluid } \\
(\mathrm{ml} / \mathrm{kg} / \mathrm{h})\end{array}$} & \multirow{2}{*}{$\begin{array}{c}\text { Excess } \\
\text { crystalloids } \\
(\mathrm{ml} / \mathrm{h})^{*}\end{array}$} & \multirow{2}{*}{$\begin{array}{c}\text { Intraoperative } \\
\mathrm{F}_{10}\end{array}$} & \multicolumn{2}{|c|}{$\mathrm{PA}-\mathrm{aO}_{2}(\mathrm{kPa})$} \\
\hline & & & Crystalloids & Colloids & & & Preoperatively $\dagger$ & Pcstoperatively $\ddagger$ \\
\hline \multicolumn{9}{|c|}{ Survivors } \\
\hline $\begin{array}{r}1 \\
2 \\
3 \\
4 \\
5 \\
6 \\
7 \\
8 \\
9 \\
10 \\
11 \\
12\end{array}$ & $\begin{array}{l}\text { RND } \\
\text { PM } \\
\text { RND } \\
\text { RND } \\
\text { RND } \\
\text { RND } \\
\text { PM } \\
\text { RND } \\
\text { RND } \\
\text { RND } \\
\text { RND } \\
\text { RND }\end{array}$ & $\begin{array}{l}7 \cdot 1 \\
2 \cdot 0 \\
6 \cdot 0 \\
5.9 \\
8 \cdot 4 \\
6 \cdot 5 \\
2 \cdot 8 \\
5.8 \\
6.0 \\
6 \cdot 3 \\
7 \cdot 1 \\
5 \cdot 8\end{array}$ & $\begin{array}{l}3.9 \\
4 \cdot 2 \\
4.9 \\
4 \cdot 2 \\
4.0 \\
3.9 \\
3.4 \\
3.7 \\
3.2 \\
3.8 \\
3.1 \\
4.2\end{array}$ & $\begin{array}{l}4 \cdot 2 \\
4 \cdot 0 \\
4 \cdot 7 \\
1 \cdot 7 \\
2 \cdot 2 \\
5 \cdot 3 \\
3 \cdot 2 \\
2 \cdot 1 \\
1 \cdot 8 \\
2 \cdot 1 \\
3 \cdot 2 \\
3 \cdot 1\end{array}$ & $\begin{array}{r}26 \\
82 \\
86 \\
301 \\
248 \\
64 \\
307 \\
56 \\
23 \\
20 \\
36 \\
268\end{array}$ & $\begin{array}{l}0.24 \\
0.25 \\
0.24 \\
0.24 \\
0.26 \\
0.25 \\
0.25 \\
0.24 \\
0.25 \\
0.24 \\
0.22 \\
0.22\end{array}$ & $\begin{array}{l}5 \cdot 8 \\
3 \cdot 8 \\
4 \cdot 1 \\
4 \cdot 6 \\
4 \cdot 8 \\
4 \cdot 9 \\
4 \cdot 0 \\
2 \cdot 5 \\
2 \cdot 9 \\
4 \cdot 6 \\
4 \cdot 8 \\
2 \cdot 6\end{array}$ & $\begin{array}{l}6.9 \\
4 \cdot 7 \\
7.0 \\
3.6 \\
8.4 \\
6 \cdot 3 \\
6.8 \\
1.3 \\
7.2 \\
2.3 \\
3.1 \\
3.2\end{array}$ \\
\hline Mean \pm SE of mean & & $5.74 \pm 0.55$ & $3 \cdot 87 \pm 0 \cdot 14$ & $3.21 \pm 0.38$ & $126 \pm 34$ & $0.24 \pm 0.003$ & $4 \cdot 1 \pm 0 \cdot 3$ & $5 \cdot 0 \pm 0 \cdot 7$ \\
\hline \multicolumn{9}{|c|}{ Non-survivors } \\
\hline $\begin{array}{l}13 \\
14 \\
15 \\
16 \\
17\end{array}$ & $\begin{array}{l}\text { PM } \\
\text { RND } \\
\text { RND } \\
\text { RND } \\
\text { RND }\end{array}$ & $\begin{array}{l}2 \cdot 1 \\
7 \cdot 3 \\
6 \cdot 8 \\
6 \cdot 0 \\
7 \cdot 1\end{array}$ & $\begin{array}{l}4 \cdot 4 \\
8 \cdot 0 \\
4 \cdot 0 \\
6 \cdot 5 \\
6 \cdot 4\end{array}$ & $\begin{array}{l}1.4 \\
3 \cdot 2 \\
0 \\
1.9 \\
5 \cdot 4\end{array}$ & $\begin{array}{l}317 \\
440 \\
171 \\
245 \\
327\end{array}$ & $\begin{array}{l}0.40 \\
0 \cdot 35 \\
0 \cdot 40 \\
0.40 \\
0.42\end{array}$ & $\begin{array}{l}5.8 \\
2.2 \\
5.5 \\
3.8 \\
6.2\end{array}$ & $\begin{array}{r}15 \cdot 0 \\
8.9 \\
14 \cdot 0 \\
17 \cdot 4 \\
22 \cdot 7\end{array}$ \\
\hline$\overline{\text { Mean } \pm S E \text { of mean }}$ & & $5.86 \pm 0.96$ & $5 \cdot 86 \pm 0 \cdot 74$ & $2 \cdot 38 \pm 0.91$ & $303 \pm 37$ & $0.39 \pm 0.01$ & $4 \cdot 7 \pm 0 \cdot 7$ & $15 \cdot 6 \pm 2 \cdot 2$ \\
\hline $\mathbf{P}$ & & NS & 0.05 & NS & 0.05 & 0.001 & NS & 0.005 \\
\hline
\end{tabular}

RND $=$ Retroperitoneal node dissection. $\quad P M=$ Removal of pulmonary metastases .

${ }^{*}$ Crystalloid intake minus urinary output. $†$ Theasured on room air. + Cases $1-12$ measured on $\mathrm{F}_{1} \mathrm{O}_{2}$ concentration of $0 \cdot 21-0 \cdot 24$; cases $13-17$ measured on $\mathrm{F}_{1} \mathrm{O}_{2}$ concentration of $0 \cdot 3$.

range of $0 \cdot 7-1.3 \mathrm{kPa}(5-10 \mathrm{~mm} \mathrm{Hg})$ in both survivors and nonsurvivors (4.1 and $4.7 \mathrm{kPa}(30.9$ and $35.4 \mathrm{~mm} \mathrm{Hg})$ respectively), but the difference between the groups was not significant. After operation, however, $\mathrm{PA}-\mathrm{aO}_{2}$ was unchanged in the survivors $(5 \mathrm{kPa}(37.9 \mathrm{~mm}$ $\mathrm{Hg})$ ) while greatly increased in the non-survivors $(15.6 \mathrm{kPa}(117.2$ $\mathrm{mm} \mathrm{Hg}) ; \mathrm{P}<0.005)$.

Statistical analysis by Pearson's product moment formula showed that the postoperative $\mathrm{F}_{\mathrm{I}} \mathrm{O}_{2}$ concentration correlated linearly with the intraoperative concentration $(P<0.001)$ but not with the volume of crystalloids administered.

\section{Discussion}

At this centre during $1970-4,100$ patients with a mean age of $26 \cdot 4 \pm \mathrm{SE}$ of mean $1 \cdot 13$ years underwent retroperitoneal node dissection or multiple wedge resection of the lung for dysgenetic neoplasm of the testes. None had received bleomycin before operation. Inspired oxygen concentrations during operation and in the postoperative period ranged from 0.35 to 0.40 . Postmortem examination of seven patients who died within 30 days of operation disclosed no evidence of pulmonary lesions compatible with the adult respiratory distress syndrome. The first five patients with similar disease who six to 12 months before operation had received bleomycin treatment according to the new protocol described died within 12 days after surgery in respiratory failure. At necropsy gross and microscopic findings of the lungs in these patients were characteristic of those attributed to the adult respiratory distress syndrome. It was suggested that the bleomycin treatment itself or in conjunction with other factors had resulted in this postoperative respiratory complication. Pulmonary lesions associated with bleomycin treatment and their relation to age, dose, and irradiation have been described..$^{4-10}$ The changes include intra-alveolar exudate, hyaline membranes, interstitial fibrosis, squamous metaplasia of type I and later type II pneumonocytes, and increased interstitial fluid in the alveolar-capillary space.

Although only six of the entire group of 17 patients studied (survivors and non-survivors) had developed moderate to moderately severe respiratory distress during bleomycin treatment, all had some restrictive disease and impaired carbon monoxide diffusion capacity (table I). The preoperative $\mathrm{PA}_{-} \mathrm{aO}_{2}$ was also greater than normal (table II). Probably, therefore, residual pulmonary effects from bleomycin were present despite the absence of clinical and radiological evidence preoperatively.

The pulmonary lesions of oxygen toxicity described by Winter and Smith ${ }^{11}$ were strikingly similar to those resulting from treatment with bleomycin. Although the inspired oxygen concentration in the non-survivors was lower than that usually associated with oxygen toxicity, possibly even these concentrations over a long period have a synergistic, detrimental effect in the presence of pulmonary tissue injured by bleomycin. On this basis the $\mathrm{F}_{1} \mathrm{O}_{2}$ was reduced to a concentration similar to or slightly above that of room air during the operation and postoperative period.

The preoperative $\mathrm{PA}-\mathrm{aO}_{2}$ in all 17 patients was measured on a $\mathrm{F}_{1} \mathrm{O}_{2}$ concentration of $0 \cdot 21$. The postoperative $\mathrm{PA}-\mathrm{aO}_{2}$ was determined in the survivors on a $\mathrm{F}_{1} \mathrm{O}_{2}$ concentration of 0.21 0.24 and in the non-survivors on a concentration of 0.30 . Pontoppidan et $a^{12}$ showed that the $\mathrm{PA}-\mathrm{aO}_{2}$ is modified by the inspired oxygen concentration. In our series the maximum difference between the preoperative and postoperative $\mathrm{F}_{1} \mathrm{O}_{2}$ concentrations was 0.09 . This small change could not account for the large increase in postoperative $\mathrm{PA}-\mathrm{aO}_{2}$ in the patients who died, which was seen in the immediate postoperative period, when the patients had no signs or symptoms of respiratory distress. Although too few patients were studied for cefinitive conclusions to be reached, the clinical evidence and statistical correlation of the $\mathrm{F}_{1} \mathrm{O}_{2}$ concentration, $\mathrm{PA}-\mathrm{aO}_{2}$, and survival rate suggest that oxygen administration may play a part in the postoperative upset and death of patients who have received bleomycin treatment a few months before operation. After this initial study was carried out the same relatively low oxygen concentration was used for 85 patients previously treated with bleomycin with no pulmonary complications or deaths.

If oxygen is a factor in the postoperative mortality of these patients its mode of action is unknown. The $\mathrm{F}_{\mathrm{I}} \mathrm{O}_{2}$ concentration used during surgery and in the immediate postoperative period in the non-survivors never exceeded 0.45 . There is no evidence that this concentration of oxygen exerts toxic effects, even when used for several weeks. ${ }^{11}$ We therefore assume that previous bleomycin treatment somehow sensitises the lung to concentrations of oxygen that do not usually produce detrimental lesions.

In addition to being given a lower $\mathrm{F}_{\mathrm{I}} \mathrm{O}_{2}$ concentration the survivors received less crystalloid and more colloid than the 
non-survivors, in accordance with the routine advocated by Skillman. ${ }^{13}$ Fluid administration was also carefully monitored with a Swan-Ganz catheter. These factors could account for some difference in pulmonary interstitial fluid between the two groups. The mean volume of crystalloid given to non-survivors, however, was not excessive (less than $6 \mathrm{ml} / \mathrm{kg} / \mathrm{h}$ ). There was also no correlation between the postoperative $\mathrm{PA}-\mathrm{aO}_{2}$, total and hourly fluid gain, or amount of colloid infused.

From this preliminary study we conclude that patients who have previously received bleomycin treatment have a greatly increased risk of developing postoperative pulmonary complications. A factor that appears to lessen this risk is a reduction in the oxygen concentration administered during operation and in the immediate postoperative period. Careful monitoring of fluid replacement, with emphasis on colloids rather than crystalloids, may play an accessory part in decreasing or preventing pulmonary interstitial oedema.

\section{References}

1 Blum, R H, Carter, S K, and Agre, K, Cancer, 1973, 31, 903.

2 Sonntag, R W, et al, Cancer Chemotherapy Reports, 1975, 59, 429.

3 Haas, C D, et al, Cancer, 1976, 38, 8.

${ }^{4}$ Luna, M A, et al, American fournal of Clinical Pathology, 1972, 38, 510.

5 Perez-Guerra, F, et al, American Review of Respiratory Diseases, 1972, 106, 909.

6 O'Neill, T J, Kardinal, C G, and Tierney, L M, Chest, 1975, 68, 265.

7 Iacovino, J R, et al, fournal of the American Medical Association, 1976, 235, 1253.

${ }^{8}$ Samuels, M L, et al, fournal of the American Medical Association, 1976, $235,1117$.

9 Einhorn, L, et al, Cancer, 1976, 37, 2414.

${ }^{10}$ Daskal, Y, et al, Cancer Research, 1976, 36, 1267.

11 Winter, P M, and Smith, G, Anesthesiology, 1972, 37, 210.

12 Pontoppidan, H, Laver, M B, and Geffin, B, in Advances in Surgery, ed C E Welch. Chicago, Year Book Medical Publishers, 1970.

${ }^{13}$ Skillman, J J, Critical Care Medicine, 1976, 4, 55.

(Accepted 26 April 1978)

\section{SHORT REPORTS}

\section{Detecting deficient energy and protein intake in hospital patients: a simple record method}

Up to half of surgical patients suffer from protein-energy malnutrition. ${ }^{12}$ A Danish study ${ }^{3}$ showed that $85 \%$ of all elderly patients in an orthopaedic surgical ward were undernourished during the entire hospital stay. These abnormalities are often unrecognised. ${ }^{2}$ Therefore a simple, inexpensive method for detecting patients who eat poorly is desirable.

\section{Patients, methods, and results}

A dietary survey was carried out on 46 consecutive patients aged over 60 admitted to an orthopaedic surgical ward. Two methods were used-(1) the precise weighing method, ${ }^{4}$ and (2) a simple record method. A full-time dietitian was responsible for the first method, in which the intake of nutrients was calculated by a computer program based on Danish food-composition tables. ${ }^{5}$ In the second method each patient was given a food-intake record sheet in the morning. The patient, his relatives, and the nursing staff (but not the dietitian) noted all foods and drinks taken during the day on the sheet-for example, $\frac{1}{2}$ hamburger, 2 potatoes, and $\frac{1}{4}$ helping of sauce; 1 slice of rye bread with cheese; 1 cup of coffee with milk; $\frac{1}{2}$ bar of chocolate; etc. Next morning the completed record sheet was sent to the kitchen, where the energy and protein intake was calculated from food-composition tables. The result was noted on the sheet and returned to the ward together with the supper.
A total of 603 one-day food-intake records were completed. Three-day records were determined as the average of three consecutive days. Nine months after the end of the test period the record sheets for the second month were also calculated by the dietitian, who did not know the results for the earlier calculations. The accuracy of the simple record method was determined by comparing the results with those of the precise weighing method. The percentile probabilities were calculated by a purely empirical method.

All the results are shown in the table.

\section{Comment}

The accuracy of one-day records was not quite satisfactory, mainly owing to a tendency to underestimate the high energy intakes. The purpose of using the simple record method in a hospital ward, however, should be to find the patients whose food intake is insufficient. The three-day records gave a correct measure of the energy and protein intake in $85-90 \%$ of patients. This degree of accuracy is satisfactory for clinical use. It can scarcely be expected that patients or staff in a busy surgical ward can record the food intake more precisely. The calculations in the kitchen from the food-composition tables were made at brief intervals by different members of the staff who never came to the ward. The results could be better if the calculations were made by a dietitian who knew the ward and had a better chance of concentrating on the work. Both in the kitchen and in the ward the routine use of the simple record method increased the interest in and the attention paid to the importance of the patient's proper food intake.

This study was supported by grants from the Medical Research Founda-

Probability of correct measurements of the energy and protein intake within the margin of \pm 200 kcal and $\pm 10 \mathrm{~g}$ and of misleadingly high and low values (divergence more than $400 \mathrm{kcal}$ or $20 \mathrm{~g}$ protein) obtained by the simple record method. The correlation coefficients are given in parentheses

\begin{tabular}{|c|c|c|c|c|c|c|c|c|c|}
\hline & \multirow{2}{*}{$\begin{array}{l}\text { Assessed } \\
\text { by }\end{array}$} & \multirow{2}{*}{ No of records } & \multirow{2}{*}{$\begin{array}{c}\begin{array}{c}\text { Correct } \\
\text { assessment } \\
(\%)\end{array} \\
\end{array}$} & \multicolumn{2}{|c|}{$\begin{array}{l}\text { Misleading } \\
\text { assessment }\end{array}$} & \multirow{2}{*}{ No of records } & \multirow{2}{*}{$\begin{array}{c}\text { Correct } \\
\text { assessment } \\
(\%) \\
(\%)\end{array}$} & \multicolumn{2}{|c|}{$\begin{array}{l}\text { Misleading } \\
\text { assessment }\end{array}$} \\
\hline & & & & $\underset{(\%)}{\operatorname{High}}$ & $\begin{array}{l}\text { Low } \\
(\%)\end{array}$ & & & $\underset{(\%)}{\text { High }}$ & $\begin{array}{l}\text { Low } \\
(\%)\end{array}$ \\
\hline & & \multicolumn{4}{|c|}{ Energy } & \multicolumn{4}{|c|}{ Energy intake $<1500 \mathrm{kcal}$} \\
\hline One-day records & $\begin{array}{l}\mathrm{K} \\
\mathrm{D}\end{array}$ & $\begin{array}{l}603 \\
238\end{array}$ & $\begin{array}{l}57(0 \cdot 86) \\
64(0.91)\end{array}$ & $\begin{array}{l}3 \\
2\end{array}$ & $\begin{array}{l}12 \\
6\end{array}$ & $\begin{array}{l}399 \\
166\end{array}$ & $\begin{array}{l}69(0 \cdot 76) \\
72(0 \cdot 78)\end{array}$ & $\begin{array}{l}3 \\
2\end{array}$ & $\begin{array}{l}2 \\
1\end{array}$ \\
\hline \multirow[t]{2}{*}{ Three-day records $\mathrm{F}$} & $\begin{array}{l}\mathrm{K} \\
\mathrm{D}\end{array}$ & $\begin{array}{l}311 \\
124\end{array}$ & $\begin{array}{l}66(0.92) \\
77(0.93)\end{array}$ & $\begin{array}{l}1 \\
0\end{array}$ & $\begin{array}{l}8 \\
1\end{array}$ & $\begin{array}{r}208 \\
92\end{array}$ & $\begin{array}{l}85(0 \cdot 77) \\
85(0 \cdot 82)\end{array}$ & $\begin{array}{l}\mathbf{0} \\
\mathbf{0}\end{array}$ & $\begin{array}{l}\mathbf{0} \\
\mathbf{0}\end{array}$ \\
\hline & & & Protein & & & \multicolumn{4}{|c|}{ Protein intake $<60 \mathrm{~g}$} \\
\hline One-day records & $\begin{array}{l}\mathrm{K} \\
\mathrm{D}\end{array}$ & $\begin{array}{l}601 \\
235\end{array}$ & $\begin{array}{l}64(0.79) \\
67(0.88)\end{array}$ & $\begin{array}{l}3 \\
3\end{array}$ & $\begin{array}{r}10 \\
0\end{array}$ & $\begin{array}{l}421 \\
172\end{array}$ & $\begin{array}{l}76(0.86) \\
69(0.93)\end{array}$ & $\begin{array}{l}4 \\
4\end{array}$ & $\begin{array}{l}2 \\
1\end{array}$ \\
\hline Three-day records & $\stackrel{\mathrm{K}}{\mathrm{D}}$ & $\begin{array}{l}307 \\
119\end{array}$ & $\begin{array}{l}72(0 \cdot 86) \\
90(0.93)\end{array}$ & $\begin{array}{l}0 \\
1\end{array}$ & $\begin{array}{l}1 \\
0\end{array}$ & $\begin{array}{r}213 \\
90\end{array}$ & $\begin{array}{l}87(0 \cdot 82) \\
90(0 \cdot 86)\end{array}$ & $\begin{array}{l}0 \\
1\end{array}$ & $\begin{array}{l}\mathbf{0} \\
\mathbf{0}\end{array}$ \\
\hline
\end{tabular}

$\mathrm{K}=$ kitchen staff. $\mathrm{D}=$ dietitian.
$1000 \mathrm{kcal} \approx 4 \cdot 2 \mathrm{MJ}$. 